\title{
Organik Ürün Tüketimi Üzerine Etkili Olan Faktörlerin Analizi; Erzurum İli Örneği
}

\author{
Ayşe Sezgin ${ }^{1}$ \\ Doç. Dr. Ahmet Semih Uzundumlu ${ }^{2 *}$
}

Geliș tarihi: 30.08 .2019

Kabul tarihi: 25.09.2019

\section{Atıf bilgisi:}

IBAD Sosyal Bilimler Dergisi

Sayı: Özel Sayı Sayfa: 441-451

Yıl: 2019

This article was checked by Turnitin. Similarity Index $25 \%$.

1Atatürk Üniversitesi, Türkiye,
asezgin2579@hotmail.com,
ORCID ID 0000-0002-9479-7326
2Atatürk Üniversitesi, Türkiye,
$\begin{aligned} & \text { asuzsemi@atauni.edu.tr, } \\ & \text { ORCID ID 0000-0001-9714-2053 }\end{aligned}$

* Sorumlu yazar

\section{öz}

Günümüzün en önemli konularından biri insan sağlığıdır. Bu bağlamda, entansif tarım ve tarım ürünlerinin insan sağlığına olan artan olumsuz etkileri, tartışılmaya başlanmış ve sağlıklı beslenme açısından organik tarımın önemi artmıştır. Organik tarım, çevre korunmasına yönelik, tarımsal çevre kirliliğini önleyebilecek ve insanlar üzerinde kimyasalların olumsuz etkilerini ortadan kaldırabilecek bir alternatif tarım yöntemi olarak ifade edilmektedir. Genel olarak organik ürünler için pazarın büyüdüğü ifade edilse de düzenli olarak organik ürün satın alanların oranı oldukça düşük kalmaktadır. Bundan ötürü çalışmada, tüketicilerin organik ürün tüketim düzeylerini etkileyen faktörler incelenmiştir. Araştırmada Erzurum ilinde 230 tüketici ile yapılan anket çalışmasından elde edilen veriler Ordered Probit Modeli kullanılarak analiz edilmiştir. Analiz sonuçlarına göre tüketicilerin organik ürün tüketme düzeyini aktif olarak çalışma durumu, aile büyüklüğü, geliri, dengeli ve sağlıklı beslenmeye dikkat etme durumu ve bilinçli tüketici olma durumlarının etkilediği sonucu ortaya çıkmıştır. Böylece tüketicilere hem dengeli ve sağlıklı beslenme hem de bilinçli alışveriş yapmaları konusunda konu uzmanlarınca kitle yayım araçları ile eğitimler verilmelidir.

Anahtar Kelimeler: Erzurum, Ordered Probit Modeli, Organik ürün, Tüketim eğilimi. 


\title{
Analysis of Factors Effecting Organic Product Consumption: A Case Study of Erzurum Province
}

\author{
Ayşe Sezgin ${ }^{1}$ \\ Assoc. Prof. Dr. Ahmet Semih Uzundumlu' ${ }^{2 *}$
}

First received: 30.08 .2019

Accepted: 25.09.2019

\section{Citation:}

IBAD Journal of Social Sciences Issue: Special Issue Pages: 441-451 Year: 2019

This article was checked by Turnitin. Similarity Index $25 \%$.

\author{
${ }^{1}$ Atatürk University, Turkey, \\ asezgin2579@hotmail.com, \\ ORCID ID 0000-0002-9479-7326 \\ 2Atatürk University, Turkey, \\ asuzsemi@atauni.edu.tr, \\ ORCID ID 0000-0001-9714-2053
}

* Corresponding Author

\begin{abstract}
One of the most important issues of today is human health. In this context, the increasing negative effects of intensive agriculture and agricultural products on human health have begun to be discussed and the importance of organic agriculture has increased in terms of healthy nutrition. Organic agriculture is defined as an alternative farming method for environmental protection, which can prevent agricultural environmental pollution and eliminate the negative effects of chemicals on humans. Although it is stated that the market for organic products is growing in general, the rate of those who regularly buy organic products is quite low. Therefore, in this study, the factors affecting the consumption levels of organic products were examined. The data obtained from the survey conducted with 230 consumers in Erzurum were analyzed using the Ordered Probit Model. According to the results of the analysis, it was found that the level of organic product consumption of the consumers affected by working status, family size, income, attention to balanced and healthy nutrition and being conscious consumers. Thus, trainings should be given to consumers by means of mass broadcasting tools by subject matter experts on both balanced and healthy nutrition and conscious shopping.
\end{abstract}

Keywords: Erzurum, Ordered Probit Model, Organic product, Consumption trend. 


\section{GİRIŞ}

Günümüzde ilerleyen teknolojiyle beraber gıda üretim teknikleri de değişmeye başlayarak üretimde çeşitlilik, maliyet avantajları ve seri üretime bağlı olarak üretim artışı meydana gelmiştir. İnsanların ihtiyaç duyduğu gıda maddelerindeki artış ve çeşitlenmeye bağlı olarak ta tüketici alışkanlıkları da değişim göstermiștir. İnsanların bu gıdaları yaygın olarak hızlı bir șekilde tüketimi başta kanser ve obezite olmak üzere birçok hastalığa yakalanmasına neden olmuştur (Spaargaren, 2011; Spaargaren vd., 2012).

Organik tarım bitkinin yetiştirilmesinden, toplanıp hasat edilmesine, nakliyesine, depolanıp muhafaza edilmesine hatta tüketiciye ulaşıncaya kadar herhangi bir kimyasal madde, tarım ilacı, gübre ve bitki düzenleyicilerinin kullanılmadığı bir üretim şeklidir (TOB, 2019). Bu tarım şeklinde asıl amaç, insanların tüketimine sunulan her türlü gıda ve besin maddelerinin yanında onların ihtiyaç duyduğu barınma ve giyinme maddelerinin üretiminde insan ve doğaya zarar vermeyecek bir üretimin yapılmasıdır (Gündüz ve Kaya, 2007). Organik tarım, ekolojik veya biyolojik tarım olarak ta isimlendirilmektedir. Bu tabirlerin ortaya çıkmasındaki en önemli etken dil farklılı̆̆ıdır. Genel anlamda bakıldığında bu kelimelerin kapsam olarak farklılı̆̆ yok denecek kadar azdır (Aytoğu, 2006; Demiryürek, 2011; Eti, 2014).

Organın tarımdaki tanımlamalarda dikkati çeken unsurlar 4 başlıkta özetlenebilir (Demiryürek, 2011);

1. Kimyasal ilaç, gübre ve hormonların kullanımı kesinlikle yasaktır.

2. Bitki besin elemanları için, bitki artıkları, hayvan gübresi kullanmakta, doğa ve çevreyi koruma ve üretimde artışı sağlama amaçlı bitki münavebesi yapılmakta ve zararlı ve yabancı ot kontrolünde biyolojik mücadele uygulanmaktadır.

3. Eko sistemi dikkate alarak bitki, toprak, hayvan ve insan sağlığını önemseyen bir üretim şekli ile tüketici tercihlerine yön vermeyi amaçlamaktadır.

4. Bu tarım şeklinin her aşaması sertifikasyon kuruluşlarının kontrolüne dayalı olarak yapılmakta başarılı üretimi yapan ürünler sertifika almaktadır.

Dünyada giderek artan ve kabul gören organik tarımın öncülüğü Avrupalı (Usal, 2006) ve ABD’li (Demiryürek, 2011) üreticiler tarafindan yapılmıştır. Bu üreticiler ürünlerini ilk zamanlarda kendileri, akrabaları veya yakın pazarlarda sattıkları bireyler tarafindan tüketilmiş tüketicilerin benimsenmesi ile beraber uzak pazarlarda da satmaya başlamışlardır. Organik ürün için giderek artan talep nedeni ile 1980'li yıllardan sonra uluslararası dünya pazarında kendine yer bulmuştur (Usal, 2006). Türkiye'de organik tarım ilk kez 1980'li yıllarda Ege Bölgesinde başlayıp bu yıldan sonra tüm bölgelerde üretimi yaygınlaşmaya başlamışıı (Eryılmaz vd., 2015).

Organik ürün kapsamında Türkiye'deki yasal düzenlemeler şu şekilde sıralanabilir; ilk yasal düzenleme "Bitkisel ve Hayvansal Ürünlerin Ekolojik Metotlarla üretilmesi ile ilgili yönetmelik" olup, 24.12.1994 tarih ve 22145 sayılı resmi gazetede yayımlanarak yürürlüğe girmiştir. Bu yönetmeliklerdeki bazı aksaklıklardan dolayı ikinci yasal düzenleme 29.06.1995 tarih ve 22328 sayılı resmi gazetede yayımlanarak yönetmelikte bazı değişiklikler yapılmıştır. Üçüncü yasal düzenleme "Organik Tarımın Esasları ve Uygulanmasına" ile ilgili yönetmelik 11.07.2002 tarih ve 24812 sayılı resmi gazetede yayımlanarak yürürlüğe girmiştir. Dördüncü yasal düzenleme 5262 sayılı "Organik Tarım Kanunu" olup, 03.12.2004 tarih ve 25659 sayılı resmi gazetede yayımlanmış ve hükümetin acil eylem planı içinde organik ürünlerin üretimi, tüketimi ve denetimine dair kanun tasarısında yer almıştır (Emir ve Demiryürek, 2014).

Son dönemlerde gıda maddelerindeki değişimler ve sağlığa olan etkileri nedeniyle tüketicilerin gıdalara bakış açısı değişerek organik ürünlere dönmeye başlamıştır (Ustaahmetoğlu ve Toklu, 2015). Ayrıca tüketicilerin bilinçlenmesi konusunda yapılan çalışmalara bağlı olarak sağlıklı ve dengeli beslenme kavramları gittikçe önemi artan konular haline gelmiştir. Bu kapsamda son zamanlarda organik gida tüketimi konusu yeni kalite merkezi olarak önemli bir yer edinmiştir (Vittersø ve Tangeland, 2015). İnsanların sağlıklı ve kaliteli gıdalara ulaşmasını sağlayacak organik pazar bölümü ortaya çıkmıştır (Ustaahmetoğlu ve Toklu, 2015). Genel olarak organik gıdalar için pazarın genişlediği 
gözlemlenmektedir (Lockie vd., 2002; Dettmann ve Dimitri, 2012). Buna karş1lk düzenli olarak organik ürün satın alan tüketicilerin oranı düşük kalmaktadır (Aertsens vd., 2011).

$\mathrm{Bu}$ araştırmanın amacı tüketicilerin organik ürün tüketim durumunu etkileyen faktörlerin belirlenmesidir. Böylece organik ürünlerin pazarlama stratejilerinin oluşturulması ve tüketici boyutunun irdelenmesi açısından önemli olacağı düşünülmektedir.

\section{MATERYAL VE YÖNTEM}

\section{MATERYAL}

Çalışmada organik ürün tüketim alışkanlığı ile ilgili tüketicileri etkileyen faktörleri belirlemek amacıyla kentsel alanlarda Erzurum ilini temsil edecek bireylerle anket çalışması yürütülmüştür. Oransal örnekleme yöntemi ile yapılacak anket sayısı tespit edilmiştir. Bu yöntemde $\% 95$ güven aralığı ve \%5 hata payı kullanılarak örneklem büyüklüğü belirlenmiştir. Anket sayısının belirlenmesinde kullanılan eşitlik Formül 1'de gösterilmiştir (Newbold, 1995; Uzundumlu vd., 2011).

$$
n=\frac{N^{*} p^{*}(1-p)}{(N-1)^{*} \sigma_{p}^{2}+p^{*}(1-p)}
$$

Formülde :

$\mathrm{n}$ : Örnek büyüklüğü,

$\mathrm{N}$ : Tüketici sayısı (hane sayısı),

$\sigma_{\mathrm{p}}^{2}:$ Varyans,

$\mathrm{r}$ : Ortalamadan sapma (\%5),

$\mathrm{Z}_{\alpha / 2}: \mathrm{Z}$ cetvel değeri (1.96),

$\mathrm{p}$ : Organik ürün tüketen hanelerin toplamdaki payı (\%82).

Çalışmada 100 ön anketle $\mathrm{p}$ ve q değerleri belirlenmiştir.

$$
\mathrm{Q}_{\mathrm{p}}{ }^{2}=\left(\frac{\mathrm{r}}{\mathrm{Z} \alpha / 2}\right)^{2}
$$

$$
\begin{aligned}
& \mathrm{Q}_{\mathrm{p}}{ }^{2}=\left(\frac{0.05}{1.96}\right)^{2}=(0.0255)^{2}=0.000651 \\
& \mathrm{n}=\frac{394684 * 0.82 * 0.18}{(394683 * 0.000651)+(0.82 * 0.18)} \cong 227
\end{aligned}
$$

Yapılacak anketlerde eksik veya yanlışların olabileceği göz önünde bulundurularak, örnek büyüklügünün $\% 1$ 'i kadar ilave anket yapılması uygun bulunmuştur. Bu kapsamda $227+(227 \times 0.01)=230$ hane ile anket çalışması yapılmıştır.

\section{YÖNTEM}

Çalışmada Erzurum ilindeki tüketicilerin organik ürün tüketim durumu üzerine etkili olan faktörleri belirlemek amacı ile organik ürün tüketim düzeyleri sorulmuştur. Her bir tüketicinin organik ürün tüketim durumu düşük, orta ve yüksek olarak sınıflandırılmıştır. Az tüketenler veya hiç tüketmeyenler (düşük) 0 , bazen tüketenler (orta) 1 ve sürekli tüketenler ise (yüksek) 2 olarak kodlanarak üç kategoriye ayrılmıştır. Böylece tüketicilerin organik ürün tüketim düzeyinde etkili olan faktörlerin belirlenmesi amacıyla Ordered Probit Modeli kullanılmıştır. Bağımlı değişkenin sıralı doğal sayı değerleri aldığı veri seti için en uygun model Ordered Probit Modelidir (McLean-Meyinsse, 1997; Boz ve Akbay, 2005; Tsui, 2014).

Bağımlı değişkenin her bir farkındalık, tutum ve davranış için 0 düşük, 1 orta ve 2 yüksek olarak kodlandığı Ordered Model aşağıdaki gibi ifade edilmiştir. 


$$
y_{i}^{*}=\boldsymbol{\beta}^{\prime} \mathbf{x}_{i}+\varepsilon_{i}, \quad \varepsilon_{i}: F\left(\varepsilon_{i} \mid \theta\right), E\left(\varepsilon_{i} \mid \mathbf{x}_{i}\right)=0, \text { and } \operatorname{Var}\left(\varepsilon_{i} \mid \mathbf{x}_{i}\right)=1
$$

$y^{*}$ bağımlı değişkenin gözlemlenemediği zaman $\boldsymbol{\beta}$ tahmin edilebilen katsayıların vektörü, $x$ açıklayıcı değişkenlerin bir vektörü, $\varepsilon$ hata terimlerinin vektörü (örneğin $\varepsilon \sim N[0,1]$ olarak normal dağılım gösterdiği kabul edilir) ve $\mathrm{F}$ ise araştırmada dikkate alınabilecek herhangi bir dağılım anlamına gelmektedir.

$$
\begin{aligned}
& y_{i}=0 \quad \text { if } y_{i} \leq \mu_{0}, \\
& y_{i}=1 \quad \text { if } \mu_{0}<y_{i} \leq \mu_{1}, \\
& y_{i}=2 \quad \text { if } \mu_{1}<y_{i} \leq \mu_{2},
\end{aligned}
$$

$\mu_{j}$, kesme noktalarını veya eşik değerlerini temsil ederken $y, y^{*}$ için gözlemlenen değerdir. Kesme noktaları katılımcıların bireysel özelliklerine göre değişmektedir.

Yukarıdaki gözlem mekanizması aşağıdaki gibi gösterilen gizli sınırlı bağımlı değişkenin tamamen sansürlenmesinin sonucudur. Benzer sosyo-ekonomik özelliklere ve çevresel farkındalıklara, tutum veya davranışlara sahip tüketicilerin benzer kesim noktalarına sahip olacağından kesme noktalarının normal dağılım göstermesi beklenmektedir (Maddala, 1983; Chen vd., 2002).

Eğer $\varepsilon$ gözlemler için normal bir şekilde dağıldığı varsayıldığında bir katılımcı tarafindan spesifik bir sıralamada seçme olasılığı aşağıdaki gibi ifade edilebilir (Chen vd., 2002; Greene 2007).

$$
\begin{aligned}
& \operatorname{Pr} o b\left[y_{i}=j\right]=\operatorname{Pr} o b\left[y_{i}^{*} \text { is in the jth range }\right]=\Phi\left(\mu_{j}-\boldsymbol{\beta}^{\prime} \mathbf{x}_{i}\right)-\Phi\left(\mu_{j-1}-\boldsymbol{\beta}^{\prime} \mathbf{x}_{i}\right) \\
& j=0,1,2 .
\end{aligned}
$$

$\Phi$ normal kümülatif yoğunluk fonksiyonu (cdf) olduğu zaman $\mu \mathrm{j}$ ve $\mu \mathrm{j}+1$ sırasıly j kategorisi için üst ve alt eşik değerlerini temsil etmektedir. $\mu-1=-\infty$ ve $\mu 0=0$ olduğunu dikkate alındığında bu olasilığın spesifik bir şekilde aşağıdaki gibidir.

$$
\begin{aligned}
& \operatorname{Pr} o b\left[y_{i}=0\right]=\Phi\left(-\boldsymbol{\beta}^{\prime} \mathbf{x}_{i}\right) \\
& \operatorname{Pr} o b\left[y_{i}=1\right]=\Phi\left(\mu_{1}-\boldsymbol{\beta}^{\prime} \mathbf{x}_{i}\right)-\Phi\left(-\boldsymbol{\beta}^{\prime} \mathbf{x}_{i}\right) \\
& \operatorname{Pr} o b\left[y_{i}=2\right]=\Phi\left(\mu_{2}-\boldsymbol{\beta}^{\prime} \mathbf{x}_{i}\right)-\Phi\left(\mu_{1}-\boldsymbol{\beta}^{\prime} \mathbf{x}_{i}\right)
\end{aligned}
$$

Log likelihood fonksiyonu;

$$
\begin{aligned}
\log L & =\sum_{i=1}^{N} \sum_{j=0}^{2} y_{i j} \log \left(\Phi\left(\mu_{j}-\boldsymbol{\beta}^{\prime} \mathbf{x}_{i}\right)-\Phi\left(\mu_{j-1}-\boldsymbol{\beta}^{\prime} \mathbf{x}_{i}\right)\right) \\
& =\sum_{y_{i}=0} \log \left(\Phi\left(-\boldsymbol{\beta}^{\prime} \mathbf{x}_{i}\right)\right)+\sum_{y_{i}=1} \log \left(\Phi\left(\mu_{1}-\boldsymbol{\beta}^{\prime} \mathbf{x}_{i}\right)-\Phi\left(-\boldsymbol{\beta}^{\prime} \mathbf{x}_{i}\right)\right)+\sum_{y_{i}=2} \log \left(\Phi\left(\mu_{2}-\boldsymbol{\beta}^{\prime} \mathbf{x}_{i}\right)-\Phi\left(\mu_{1}-\boldsymbol{\beta}^{\prime} \mathbf{x}_{i}\right)\right)
\end{aligned}
$$

\section{BULGULAR VE TARTIŞMA}

\section{Deskriptif Analiz Sonuçları}

Araştırmada Erzurum ilinde 230 tüketici ile görüşmeler yapılmış ve incelenen değişkenlerin istatistiki özeti ve açıklamaları Tablo 1'de verilmiştir. 
Tablo 1. Değişkenlerin istatistik özet ve açıklamaları

\begin{tabular}{|c|c|c|c|}
\hline Değişkenler & Açıklamaları & Ortalama & Sd Hata \\
\hline Yaş & Anket yapılan bireyin yaş1 & 38.008 & 12.730 \\
\hline Cinsiyet & Erkek:1, Kadın:0 & 0.652 & 0.031 \\
\hline Medeni durum & Evli:1, Bekar:0 & 0.660 & 0.031 \\
\hline Eğitim durumu & $\begin{array}{l}\text { Okur-yazar:1, } \\
\text { İlköğretim:2, } \\
\text { Ortaöğretim:3, } \\
\text { Üniversite:4, } \\
\text { Lisansüstü:5 }\end{array}$ & 3.304 & 0.931 \\
\hline Çalışma durumu & Evet:1, Hayır:0 & 0.613 & 0.488 \\
\hline Aile büyüklüğü & Ailedeki birey sayıs1 & 4.257 & 1.845 \\
\hline Gelir & Hane halk1 geliri (Ay/TL) & 3309.348 & 1927.442 \\
\hline Dengeli ve sağlıklı beslenme durumu & Hayır:0, Bazen:1, Evet: 2, & 1.074 & 0.787 \\
\hline Bilinçli tüketici olma durumu & Hayır:0, Bazen:1, Evet: 2, & 1.465 & 0.658 \\
\hline Fiyat araştırması yapma durumu & Evet:1, Hayır:0 & 0.778 & 0.416 \\
\hline Kalite araştırması yapma durumu & Evet:1, Hayır:0 & 0.857 & 0.351 \\
\hline Organik ürün hakkında bilgili olma durumu & $\begin{array}{l}\text { Hayır:0, } \\
\text { Bazen:1, } \\
\text { Evet:2, }\end{array}$ & 1.352 & 0.713 \\
\hline $\begin{array}{l}\text { Ürünün organik sertifikasını kontrol etme } \\
\text { durumu }\end{array}$ & Hayır:0, Bazen:1, Evet:2, & 0.935 & 0.825 \\
\hline
\end{tabular}

Çalışmaya katılan tüketicilerin yaş ortalamasının yaklaşık 38, \%66'sının evli ve \%65'inin erkek olduğu belirlenmiştir. Yüzbaşıŏlu ve Kızıloğlu (2019), 2017 yılı için Erzurum ilinde görüştükleri 272 bireyin yaş ortalamasını 35.04 yıl, medeni durum olarak \%76'sının evli ve \%54'ünün erkek olduğunu belirtirken, Uzundumlu vd. (2018) 2018 yılı verilerine göre aynı bölgede 400 kişinin yaş ortalamasını 37.54 yıl, medeni durum bakımından \%53 ünün evli ve cinsiyet bakımından \%50'sinin erkek olduğunu tespit etmişlerdir.

Çalışmaya katılanların eğitim seviyelerinin genelde ortaöğretim düzeyine sahip oldukları tespit edilmiştir. Yüzbaşıŏlu ve Kızıloğlu (2019), lise ve altında eğitim gören bireylerin oranını \%63.24 olarak tespit ederken, Uzundumlu vd. (2018), ise bireylerin eğitimini 12.28 yıl olarak lise düzeyinde bir ortalama hesaplamışlardır.

Ayrıca anket yapılan bireylerin \%61'inin gelir getiren bir mesleğe sahip olduğu ve ortalama aile büyüklüğünün ise 4.3 bireyden oluştuğu Tablode verilmiștir. Uzundumlu vd. (2018), anket yapılan bireylerden \%42'sinin gelir getiren bir mesleğe sahip olduğu, \%30'unun öğrenci, \%8'i işsiz ve \%20'si ise ev hanımlarından oluştuğu ve hanelerde yaşayan birey sayısını 4.35 kişi olarak belirlemişlerdir.

Hanelerin ortalama 3309 TL aylık gelire sahip olduğu ve dengeli ve sağlıklı beslenmeye bazen dikkat ettikleri tespit edilmiştir. Uzundumlu vd. (2018), aylık aile gelirini 4300 TL ve Yüzbaşığlu ve Kızıloğlu (2019), ise 2572.72 TL olarak hesaplamışlardır. Zemzemoğlu vd. (2019), öğrencilerin çoğunluğunun yemek yeme de öğün atladığını ve bu öğün atlama aşamasındaki en büyük etkenin zaman kısıtlılığı ve sağlıklı beslenme konusundaki vurdumduymazlık olduğunu tespit etmişlerdir.

Ayrıca çalışmaya katılan tüketicilerin bilinçli tüketici olup olmadıkları 5'li likert ölçeğine göre (hiç:1, bazen:2, yarı yarıya:3, genelde:4 ve her zaman:5) 4 kategoride incelenmiştir.

1. Tüketicinin alışverişe çıkmadan önce liste yapma, alışveriş yaparken etikete bakma, çevreye dost ürün veya ambalaj kullanılma durumunu inceleme, son kullanma tarihine dikkat etme ve alışverişten sonra fiş alma gibi unsurlara duyarlılık dereceleri,

2. Tüketicilerin ürünün garantisi veya markaya ne ölçüde dikkat ettiği,

3. Tüketicilerin ürün satın alırken fiyata verdiği önem derecesi,

4. Tüketici olarak tüketici haklarını ne ölçüde bildikleri ile ilgili sorular sorulmuştur.

Burada 1 ve 2 cevaplarını sıfır, 3 cevabı bir ve 4 ve 5 cevapları ise iki katsayısı olarak dikkate alınarak analize tabi tutulmuştur. Sonuçta tüketicilerin genelde alışveriş bilincine sahip oldukları tespit edilmiştir.

Tüketicilerin \%77.8'i fiyat araştırması ve \%85.7'si ise kalite araştırması yapmaktadır. 
Tüketicilerin ürün hakkında bilgi düzeylerini belirlemek için 5'li likert ölçeğine göre (hiç:1, bazen:2, yarı yarıya:3, genelde:4 ve her zaman:5) 4 soru sorulmuştur.

1. Organik ürünlerin üretimden tüketime kadar hangi aşamada kimyasal madde ve tarımsal ilaç hormon kullanılmaması gerektiği,

2. Organik üretimin hangi aşamasında sertifikasyon işlemine tabi tutulduğu,

3. Organik ürünler de organik ürün etiketi hakkında bilgi düzeyi ve

4. Geleneksel veya köy tipi ürünler ne ölçüde organiktir. (Hiç:5 ve herzaman:1)

Bu dört soruya toplamda 1,2,3 değerini verenler (0), 4 değerini verenler (1) ve 5 değerini verenler (2), olarak değerlendirerek analize tabi tutulmuştur.

Ayrıca tüketicilerin organik ürün hakkında kısmen bilgi sahibi oldukları görülürken, ürünün organik sertifikasını kontrol etme oranının düşük olduğu belirlenmiştir. Sarıkaya (2007), İnci vd. (2014) ve İnci vd. (2017), tüketicilerin organik ürünler hakkında yararlandıkları bilgi kaynaklarını internet, eş dost tavsiyesi, televizyon, dergi-gazete ve satış elemanları olarak sıralamaktadırlar.

\section{Odered Probit Analiz Sonuçları}

Çalışmada Erzurum ilinde tüketicilerin organik ürün tüketim durumları, düşük, orta ve yüksek sıralamasına göre üç kategoriye ayırıp Odered Probit Modelinde analizine tabi tutulmuş ve sonuçlar Tablo 2'de verilmiştir.

Tablo 2. Organik ürün tüketme durumuna göre ordered probit analiz sonuçları

\begin{tabular}{|c|c|c|c|c|c|}
\hline \multicolumn{3}{|c|}{ Ordered olasılık modeli parametreleri } & \multicolumn{3}{|c|}{ Marjinal Etkiler } \\
\hline & & & $\mathrm{Y}=\mathbf{0}$ & $Y=1$ & $\mathrm{Y}=2$ \\
\hline Değişkenler & Katsayı & Sd. Hata & Katsayı & Katsayı & Katsayı \\
\hline Yaş & -0.0017 & 0.0066 & 0.0004 & 0.0003 & -0.0007 \\
\hline Cinsiyet & 0.0533 & 0.2992 & -0.0124 & -0.0088 & 0.0212 \\
\hline Medeni durum & -0.1424 & 0.1957 & 0.0321 & 0.0246 & -0.0567 \\
\hline Eğitim durumu & -0.0463 & 0.0911 & 0.0107 & 0.0078 & -0.0184 \\
\hline Çalışma durumu & $0.8085 * * *$ & $\mathbf{0 . 1 8 1 7}$ & $-0.2039 * * *$ & $-0.1057 * * *$ & $0.3097 * * *$ \\
\hline Hane büyüklüğü & $0.1005 * *$ & 0.0464 & $-0.0232 * *$ & $-0.0168 * *$ & $0.0399 * *$ \\
\hline Gelir & $0.0001^{*}$ & 0.0001 & $-0.0001^{*}$ & $0.0001^{*}$ & $0.0001^{*}$ \\
\hline Dengeli ve sağlıklı beslenmeye dikkate etme durumu & $0.2824 * * *$ & $\mathbf{0 . 1 0 6 3}$ & $-0.0652 * * *$ & $-0.0471 * *$ & $\mathbf{0 . 1 1 2 3} * * *$ \\
\hline Bilinçli tüketici olma durumu & $0.3944 * * *$ & $\mathbf{0 . 1 3 4 7}$ & $-0.0911 * * *$ & $-0.0658 * *$ & $0.1569 * * *$ \\
\hline FIYAT araştırması yapma durumu & -0.1082 & 0.2902 & 0.0242 & 0.0189 & -0.0431 \\
\hline KALİTE araştırmas1 yapma durumu & 0.1975 & 0.2877 & -0.0489 & -0.0288 & 0.0778 \\
\hline Organik ürün hakkında bilgi sahibi olma durumu & -0.1266 & 0.1140 & 0.0292 & 0.0211 & -0.0504 \\
\hline Organik ürünün sertifikasını kontrol etme durumu & 0.0487 & 0.1010 & -0.0113 & -0.0081 & 0.0194 \\
\hline Mu1 & -0.7384 & 0.6295 & & & \\
\hline Mu2 & $1.1242 * * *$ & 0.1075 & & & \\
\hline
\end{tabular}

Analiz sonuçlarına bakıldığında parametrelerin işaretlerinin genelde beklenen yönde olduğu görülmektedir. İstatistiki açıdan önemli olan değişkenler dikkate alındığında tüketicilerin fiilen çalışıyor olması organik ürün tüketimini arttırmakta ve bu değişkenin \%1 önem seviyesinde önemli olduğu görülmektedir. Çalışma durumu düşük organik ürün tüketim oranını yaklaşık \%20, orta düzeyde tüketim oranını ise yaklaşık \%11 azaltırken yüksek düzeyde tüketim oranını yaklaşık \%31 arttırmaktadır. İnsanların çalışma hayatı içerisinde yer alması birçok konuda bilinçli ve bilgi sahibi olmasını sağladığı için böyle bir sonucun ortaya çıkmasına neden olduğu ifade edilebilir. Hanelerdeki birey sayısının artması organik ürün tüketim düzeyini artırdığı ve bu değişkenin istatistik açıdan (\%5) önemli olduğu belirlenmiştir. Hane büyüklügü düşük ve orta düzeyde organik ürün tüketenlerin oranını yaklaşık $\% 2$ azalttığı ve yüksek düzeyde tüketenlerin oranını yaklaşık $\% 4$ arttırdığ 1 tespit edilmiştir. Bu durumda hanedeki birey sayısının artması haneye gelir getiren kişi sayısında arttırmakta ve bu nedenle daha sağlıklı gıdalar için aileler daha fazla ödeme yapmak istemektedirler. Aylık gelirin organik ürün üzerine pozitif yönde ve istatistiki açıdan (\%10)'da önemlidir. Gelir için marjinal etkilere bakıldığında etki oranın oldukça düşük olduğu görülmektedir. Gelirin tüketimi olumlu yönde etkilemesi ve özellikle de organik ürün tüketimini artırıcı bir faktör olması beklenen bir sonuçtur. Gelirin artması durumunda 
düşük organik ürün tüketen grupta organik ürün tüketim oranı $\% 0.01$ azalırken orta ve yüksek organik ürün tüketen gruplarda \%0.01 artmaktadır. Dettmann ve Dimitri (2012), hane reisinin gelir ve eğitim düzeyindeki artış organik sebze tüketimi üzerine pozitif etkilidir. Bahşi ve Akça (2019), organik ürünlerin fiyatları konvansiyonel ürünlere göre 3-5 kat daha fazla olması geliri yüksek ailelerin organik ürün talebinin daha fazla olmasına neden olmaktadır. Ancak 1000 TL ve altında gelire sahip olan ailelerde organik ürün kullandığını ifade edenlerin oranı \%50'nin üzerindedir. Bunun anlamı tüketicilerin köyden gelen veya kendi evde yapmış oldukları ürünleri organik olarak düşürülmesinden kaynaklanmaktadır. Varoğlu ve Turhan (2016), tüketicilerin önemli bir kısmı köy ürünlerinin organik ürün olarak düşünmektedir. Çünkü piyasada köy ürünlerini organik ürün olarak reklam yapıp satan işletme sayısı fazlasıyla vardır. Köy ürünleri organik ürün değildir. Çünkü organik ürünlerin her aşaması kontrollü ve sertifikalı olarak yapılmaktadır. Bu nedenle tüketicilerin büyük bir çoğunluğu organik ürün tanımlamasını tam anlamıyla bilmemektedir. Ayrıca Karabaş ve Gürler (2012), hane halkında aileye gelir getiren kişinin bir birim artması hane halkının organik ürün tüketim miktarını 1.2 kat arttırdığını tespit etmişlerdir. Ayrıca Eti (2014), doktora tezinde organik ürünler için fiyatın \%10, \%20 ve \%30 artışına karşı tüketicilerin giderek azalan oranlarda organik ürünü tercih ettiğini belirlemiştir. $\mathrm{Bu}$ anlamda hanede çalışan sayısının artması veya hane gelirinin artması organik ürün talebini artırdığını tespit etmiştir. Bahşi ve Akça (2019), üreticilerin organik ürünlerin fiyatlarının düşmesi için organik üretimin artması gerektiğini düşünenlerin oranını $\% 50$, çiftlere destek verilmesini önerenlerin oranını $\% 30$ ve aracıların etkisini azaltılması gerektiğini savunanların oranını $\% 20$ olarak tespit etmiştir

Dengeli ve sağlıklı beslenme konusuna duyarlı olan tüketiciler düşük organik ürün tüketim oranını yaklaşık $\% 7$ azaltırken, orta düzeyde tüketim düzeyini $\% 5$ azaltıp, yüksek düzeyde tüketim oranını ise \%11 artırdığg tespit edilmiştir. Organik olmayan ürünlerin sağlığa olan olumsuz etkileri konusu birçok platformda dile getirilen ve toplumda bilinç oluşturulan bir konudur. Bu nedenle dengeli ve sağlıklı beslenme konusunda organik ürün tüketiminin önemi açık bir şekilde görüldüğü için böyle bir sonucun ortaya çıkması beklenen bir sonuçtur. Bu sonucu destekleyen bir çalışma yapan De Magistris ve Gracia (2008) tüketicilerin ödeme istekleri dikkate alındığında çevreyi koruyucu, sağlkklı ve dengeli bir beslenme arzulayan tüketicilerin daha fazla fiyatı ödeyerek organik ürünlere yöneldiklerini tespit etmiştir. Vittersø ve Tangeland (2015), marketlerde organik gıdaların son yıllarda artışına rağmen etiketleme sistemine ve organik gıdaların kalitesi gibi benzeri faktörler için tüketicilerin güven algıları daha şüpheci hale gelmiştir.

Bireylerin bilinçli bir tüketici olduğunu ifade etme durumu organik ürün tüketim düzeyini olumlu yönde ve istatistiki açıdan \%1 önem seviyesinde artırdığı tespit edilmiştir. Düşük oranda organik ürün tüketen $\% 9$ ve orta düzeyde organik ürün tüketenlerin oranını ise $\% 7$ azaltırken, yüksek düzeyde organik ürün tüketenlerin oranını ise yaklaşık \%16 arttırdığı tespit edilmiştir. Vittersø ve Tangeland, (2015), organik gıda tüketimini artırmada tüketici bilgileri ve gıda etiketleme şemalarının önemli bir yere sahip olduğunu, Eti (2014), ise bireylerin ürün satın alırken daha bilinçli olması organik ürün talebini artırdığını bu artan talep doğrultusunda organik ürün arz edenlerin organik üretime yönelik birtakım çalışmaları yapması gerektiğini vurgulamıştır. Aertsens vd. (2011), tüketicilerin organik gıdaya ilişkin nesnel ve sübjektif bilgi seviyelerinin artması ve daha fazla deneyim ve bilinçli olması, organik gidalara karşı daha olumlu bir tutum yansıttığını belirtmiştir. Lockie vd. (2002), Avustralya'da artan tüketici talebine ayak uydurmakta zorlanan organik üretimi üreticiye teşvik etme yollarını araştırmaktadır. Çünkü son 1 yılda en az bir kez sertifikalı organik ürün tüketen hanelerin oranını $\% 80$ olarak belirlemişlerdir. Sancaktar Meral (2019) tutundurma faaliyetleri kapsamında bir ürünün çevreye duyarlılığının ön plana çıkarılmasına yönelik reklamların bilinçli tüketiciyi etkilemediği ancak bu konuda bilgi sahibi olmayan tüketicileri daha çok etkilediğini göstermiştir.

\section{SONUÇ VE ÖNERILER}

Çalışmada her bir tüketici segmentine göre organik ürün tüketimi üzerindeki olan faktörleri tespit etmek için ordered probit modelinden yararlanılmıştır. Çalışma sonuçlarına göre kullanılan 13 faktörden 5'i istatistiki açıdan önemli olup, bu faktörler ailedeki gelir getiren kişi sayısı, hane büyüklüğü, hane geliri, bireyin besin sağlığı ve değerine dikkat etme tutumu ve bireyin kendini bilinçli tüketici görme durumudur. Bu beş faktörden dördü tüketici segmentlerinde ayn1 yönde etki verdiği tespit edilmiştir. Hane geliri dışındaki haneye gelir getiren kişi sayısı, hane büyüklüğü, bireyin sağlık ve besin değerini 
dikkat etme tutumu ve bireyin kendini bilinçli tüketici görme durumu arttıkça düşük ve orta düzeyde organik ürün tüketen hanelerin organik ürün tüketim düzeyi azalırken, yüksek düzeyde organik ürünü tüketen hanelerin tüketim oranı artmaktadır. Bu durum hane geliri açısından incelendiğinde ise hanelerdeki gelir arttıkça düşük organik ürün tüketen grubun organik ürün tüketim miktarı azalmakta, orta ve yüksek düzeyde organik ürün tüketen hanelerin organik ürün tüketim miktanı artmaktadır. Sonuç olarak Erzurum ilinde tüketicilerin organik ürün tüketim eğiliminin artmasında hane geliri ve bu gelire dolaylı yollardan etkili olan hane birey sayısı ve bireyin gelir getirici bir faaliyet ile uğraşması gibi faktörler etkili olmaktadır. Ekonomik koşullar organik ürün tüketimi üzerine etkili olan en önemli faktördür. Organik ürünün fiyatındaki küçük değişimler de bile talebinde büyük bir değişim olacağı düşünülmektedir. $\mathrm{Bu}$ nedenle organik üretimde bulunan işletmelerin maliyet ve etkinlik çalışmaları yapılarak ve aracıların etkisi zayıflayarak fiyattaki düşüşler ile tüketici talebi bu ilde artırılabilir. Ayrıca tüketicilerin organik ürünler hakkında bilgi seviyesi ve sağlığa olan önemli katkılarına yönelik araştırmalar yapmaları da onların organik ürün talebine önemli ölçüde katkı sağlamaktadır. Tüketici sağlığı ve organik ürünler hakkında TV, radyo, internet gibi kitle yayım ve iletişim araçlarıyla yapılacak bilgilendirme çalışmaları ile tüketicilerin organik ürünlere olan talepleri artırılabilir. Toplumda organik ürün bilinci, çevrenin korunması ve sağlıklı gıdalara ulaşımla ilgili bilgilendirme çalışmaları ile kişilerin kahve veya eğlence alanlarında geçirdikleri zamanın bir kısmını gelir getirici bir faaliyete ayırması sağlandığında yani bireylerin girişimcilik ruhu arttırıldığında hem organik üretim yapan birey sayısı hem de organik ürün tüketimi artacaktır.

Bilgilendirme / Acknowledgement: Bu çalışma 3. International Balkan and Near Eastern Social Sciences Congress Series - Edirne / Turkey sunulmuştur.

\section{KAYNAKÇA}

Aertsens, J., Mondelaers, K., Verbeke, W., Buysse, J. and Van Huylenbroeck, G. (2011). The influence of subjective and objective knowledge on attitude, motivations and consumption of organic food. British Food Journal, 113(11), 1353-1378.

Aytoğu R.K. (2006). Organik tarm analizi ve AB pazarı firsatt. İstanbul: İstanbul Ticaret Odas1 Yayınları.

Bahşi, N. ve Akça, A.D. (2019). Tüketicilerin organik tarım ürünlerine bakış açılarının belirlenmesi üzerine bir araştırma: Osmaniye ve Şanlıurfa illeri örneği. Kahramanmaraş Sütçü İmam Üniversitesi Tarım ve Doğa Dergisi, 22(1), 26-34.

Boz, I. and Akbay, C. (2005). Factors influencing the adoption of maize in Kahramanmaras province of Turkey. Agricultural Economics, 33, 431-440.

Chen, K., Ali, M., Veeman, M., Unterschultz, J. and Le, T. (2002). Relative importance rankings for pork attributes by Asian-origin consumers in California: applying an ordered probit model to a choice-based sample. Journal of Agricultural and Applied Economics, 34(1), 67-79.

De Magistris, T. and Gracia, A. (2008). The decision to buy organic food products in southern Italy. British Food Journal, 110(9), 929-947.

Demiryürek, K. (2011). Organik tarım kavramı ve organik tarımın dünya ve Türkiye'deki durumu. GOÜ, Ziraat Fakültesi Dergisi, 28(1), 27-36.

Dettmann, R.L. and Dimitri, C. (2012). Who's buying organic vegetables? Demographic characteristics of us consumers. Journal of Food Products Marketing, 16, 79-91.

Emir, M. ve Demiryürek, K. (2014). Avrupa birliği ve Türkiye'deki organik tarım mevzuatındaki gelişmeler ve son yönetmeliklerin analizi. Adnan Menderes Üniversitesi Ziraat Fakültesi Dergisi, $11(2), 21-28$. 
Eryılmaz, G.A., Demiryürek, K. ve Emir, M. (2015). Avrupa birliği ve Türkiye'de organik tarım ve gida ürünlerine karşı tüketici davranışları. Anadolu Tarım Bilimleri Dergisi, 30(2), 199-206.

Eti, H.S. (2014). Organik gıdaların pazarlanması ve organik gıdalara karşı tüketici tutum ve davranışları analizi. Yayınlanmamış doktora tezi, Namık Kemal Üniversitesi, Tekirdağ.

Greene, W. (2007). Econometric analysis. $6^{\text {th }}$ edition. New York: Prentice Hall.

Gündüz, A.Y. ve Kaya, M. (2007). Avrupa birliği tarım politikası ve Türkiye'de organik tarımın gelişimi üzerine olas1 etkisi. Elektronik Sosyal Bilimler Dergisi, 6, 305-330.

İnci, H., Karakaya, E., Söğüt, B., Şengül, T. (2014). Organic product consumption and customer preferences in urban sections of Bingol province. Türk Tartm ve Doğa Bilimleri Dergisi 1(2), 255261.

İnci, H., Karakaya, E. ve Şengül, A.Y. (2017). Organik ürün tüketimini etkileyen faktörler (Diyarbakır ili örneği). KSÜ Doğa Bilimleri Dergisi, 20(2), 137-147.

Karabaş, S. ve Gürler, A.Z. (2012). Organik ürün tercihinde tüketici davranışları üzerine etkili faktörlerin logit regresyon analizi ile tahminlenmesi. Adlyaman Üniversitesi Sosyal Bilimler Enstitüsü Dergisi, 2012(10), 129-156.

Lockie, S., Lyons, K., Lawrence, G. and Mummery, K. (2002). Eating 'green': motivations behind organic food consumption in Australia. Sociology Ruralis, 42(1), 23-40.

Maddala, G.S. (1983). Limited-dependent and qualitative variables in econometrics. Cambridge: Cambridge University Press.

McLean-Meyinsse, P.E. (1997). Factors influencing early adoption of new food products in Louisiana and Texas. Journal of Food Distribution Research, 28(3), 1-10.

Newbold, P. (1995). Statistics for business and economics. New York: Prentice Hall Inc.

Sancaktar Meral, G. (2019). Yeşil pazarlama kapsamında tüketicilerin organik gıda tercihlerinin incelenmesi. Yayınlanmamış yüksek lisans tezi, Kırklareli Üniversitesi, Kırklareli.

Sarıkaya, N. (2007). Organik ürün tüketimini etkileyen faktörler ve tutumlar üzerine bir saha çalışması. Kocaeli Üniversitesi Sosyal Bilimler Dergisi, 14, 110-125.

Spaargaren, G. (2011). Theories of practices: agency, technology, and culture: exploring the relevance of practice theories for the governance of sustainable consumption practices in the new world-order. Global Environmental Change, 21(3), 813-822.

Spaargaren, G., Oosterveer, P. and Loeber, A. (2012). Food practices in transition: changing food consumption, retail and production in the age of reflexive modernity. New York: Routledge.

TOB. (2019). Organik tarım. 24 Ağustos 2019 tarihinde http://www.tarim.gov.tr/Konular/BitkiselUretim/Organik-Tarim/Genel-Bilgiler adresinden erişilmiştir.

Tsui, H.C. (2014). What affects happiness: absolute income, relative income or expected income? Journal of Policy Modeling, 36(6), 994-1007.

Usal, G. (2006). Toros dăg köylerinde organik tarım yoluyla üretici gelirlerini artırma olanakları. Yayınlanmamış doktora tezi, Çukurova Üniversitesi, Adana.

Ustaahmetoğlu, E. ve Toklu, İ.T. (2015). Organik gıda satın alma niyetinde tutum, sağglk bilinci ve glda güvenliğinin etkisi üzerine bir araştırma. AIBBÜ-İIBF Ekonomik ve Sosyal Araştırmalar Dergisi, 11(1), 197-211.

Uzundumlu, A.S., Aksoy, A. ve Işık, H.B. (2011). Arıcıllk işletmelerinde mevcut yapı ve temel sorunlar: Bingöl ili örneği. Atatürk Üniversitesi, Ziraat Fakültesi Dergisi, 42(1), 49-55.

Uzundumlu, A.S., Kurtoğlu, S. ve Ertek, N. (2018). Erzurum ilinde tüketicilerin elma çeşidi tercihi üzerinde etkili olan faktörlerin belirlenmesi. ASOS Journal, 6(76), 107-119. 
Varoğlu, S.T. ve Turhan, Ș. (2016). Consumption trend of organic product and determination of consumer profile: A case study of Sakarya. Gaziosmanpașa Üniversitesi Ziraat Fakültesi Dergisi, 33(3), 189-196.

Vittersø, G. and Tangeland, T. (2015). The role of consumers in transitions towards sustainable food consumption. The case of organic food in Norway. Journal of Cleaner Production, 92, 91-99.

Yüzbaşığlu, R. ve Kızıloğlu, S. (2019). Tıbbi-aromatik bitkilerin satın alımında bireylerin bilinç düzeyi (Erzurum merkez ilçeleri örneği). Ağri İbrahim Çeçen Üniversitesi Sosyal Bilimler Enstitüsü Dergisi, 5(1), 119-132.

Zemzemoğlu, T.E.A., Erem, S., Uludağ, E. ve Uzun, S. (2019). Sağlık bilimleri fakültesi öğrencilerinin beslenme alışkanlıklarının belirlenmesi. Food and Health, 5(3), 185-196. 